Historic, archived document

Do not assume content reflects current scientific knowledge, policies, or practices. 


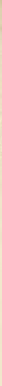

U. S. DEPARTMENT OF AGRICULTURE, FOREST SERVICE - Circular 36 (Fourth Edition).

GIFFORD PINCHOT, Forester.

\section{THE FOREST SERVICE:}

WHAT IT IS

AND HOW IT DEALS WITH

FOREST PROBLEMS. 


\section{ORGANIZATION OF THE FOREST SERVICE.}

Gifford Pinchot, Forester.

Overton W. Price, Associate Forester.

P. P. Wells, Law Officer.

Herbert A. Smith, Editor.

George B. Sudworth, Dendrologist.

Operation-James B. Adams, Assistant Forester, in Charge.

Maintenance-l lermon C. Metcalf, Chief.

Accounts-George E. King, Chief.

Organization-C. S. Chapman, Chief.

Clyde Leavitt, Assistant Chief.

Engineering-W. E. Herring, Chief.

Lands-George F. Pollock, Chief.

Silviculture-William T. Cox, Assistant Forester, in Charge.

Extension-Samuel N. Spring, Chief.

Silvics-Raphael Zon, Chief.

Management-E. E. CARTER, Chief.

W. G. Weigle, Assistant Chief.

Grazing-Albert F. Pотter, Assistant Forester, in Charge.

Products-William L. Hall, Assistant Forester, in Charge.

Wood Utilization-R. S. Kellogg, Chief.

Wood Preservation-CarL G. Crawford, Chief.

Publication-Findley Burns, Chief. 


\section{LETTER OF TRANSMITTAL.}

\section{U. S. Department of Agriculture, \\ Forest Service,}

Washington, D. C., October 16, $190 \%$.

SIR: I have the honor to transmit herewith a manuscript entitled "The Forest Service: What It Is and How It Deals with Forest Problems," and to recommend its publication as the fourth edition of Circular 36 of the Forest Service.

The figure which accompanies the manuscript is necessary for a proper understanding of the subject.

Very respectfully,

Gifford Pinchot,

Forester.

Hon. James Wilson,

Secretary of Agriculture.

[Cir. 36] 


\section{TO THE PUBLIC.}

The Forest Service exists to promote forestry throughout the whole country, for every practical purpose and for the benefit of all. Its knowledge, advice, and cooperation are at the disposal of all forest users.

Those who desire to practice forestry on their timberlands or wood lots should apply for Circular 21, which explains the terms of cooperation offered.

Those who desire to plant or improve forest plantations shoulc apply for Circular 22, which explains the cooperative terms offered for this work.

Following the necessary official action on the part of any State, cooperative studies of State forest problems will be undertaken.

Questions about the National Forests, about tree species, about the strength, mechanical qualities, preservative treatment, or commercial use of woods, about woods for special purposes, as well as about forests, forest products, and the industries depending upon them, will be carefully answered.

Information upon forest legislation may be sought.

All communications should be addressed to

The Forester,

U. S. Department of Agriculture, W AShington, D. C. 


\section{CONTENTS.}

Page.

Organization of the Forest Service . . . . . . . . . . . . . . . . . . . . . . . . . . 8

Office of the Forester . . . . . . . . . . . . . . . . . . . . . . . . . . . . . . . . . . . . 10

Law officer............................................... 10

Editor . . . . . . . . . . .

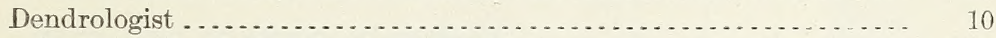

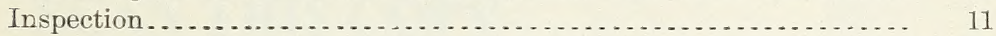

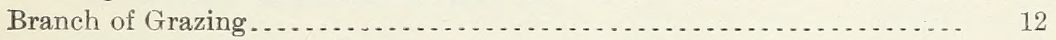

Office of Control. . . . . . . . . . . . . . . . . . . . . . . . . . . . . . . 12

Office of Development ................................. 12

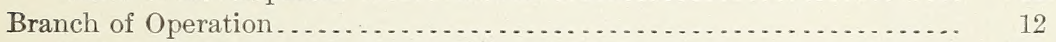

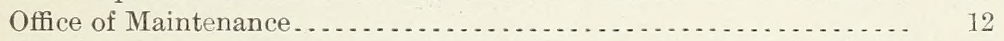

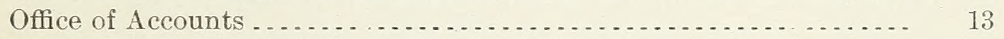

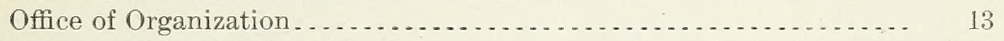

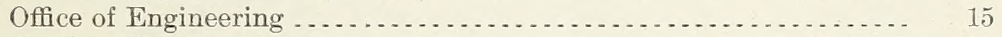

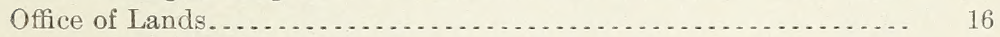

Branch of Silviculture . . . . . . . . . . . . . . . . . . . . . . . . . . . . 19

Office of Extension . . . . . . . . . . . . . . . . . . . . . . . . . . . . . . 19

Office of Silvics.............................................. 21

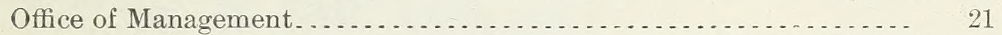

Branch of Products .........

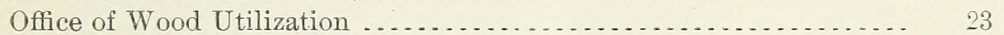

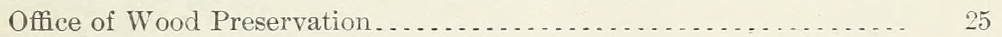

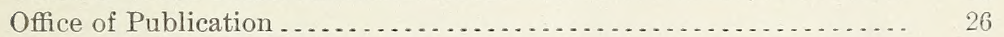

Classified list of publications and guide to their contents . . . . . . . . . . . $\quad 27$

Location and area of the National Forests . . . . . . . . . . . . . . 35

\section{ILLUSTRATION.}

Chart of the organization of the Forest Service. 



\section{THE FOREST SERVICE: WHAT IT IS AND HOW IT DEALS WITH FOREST PROBLEMS.}

"Forest Service" has been the name since July 1, 1905, of that branch of the Department of Agriculture which was previously called the "Bureau of Forestry," and, earlier still, the "Division of Forestry."

Since February 1, 1905, the Forest Service has been charged, under the direction of the Secretary of Agriculture, with the administration of the National Forests. About the management of the National Forests, therefore, the work of the Service now centers. The Forests, whose area on October 1, 1907, was 158,809,459 acres, are of vital importance for their timber and grass and for the conservation of stream flow. They are so managed as to develop their permanent value as a resource by use. Opposition toward them, based on the belief that preservation would prevent use, has changed with the understanding of their real object to approval and support. The last valid objections to their establishment and maintenance have been removed by the Agricultural Settlement law of June 11, 1906, and by a clause in the agricultural appropriation act for the year 1906-7. By the first, agricultural land in National Forests, if classified as chiefiy valuable for agriculture, listed in the local land office, and opened by the Secretary of the Interior, may be taken up by home builders. ${ }^{a}$ Many small tracts of agricultural lands, scattered here and there along creeks and valleys, have unavoidably been included within Forest boundaries, though the utmost care secured the elimination of all large bodies of such land when the boundaries were drawn. 'The need of such a law as that of June 11 was clearly seen, and its passage was secured.

The so-called "ten per cent clause" of the agricultural appropriation bill provides that States having Forests are to receive 10 per cent of the gross receipts from the Forests within their boundaries, to be distributed among the counties in which the Forests lie and devoted to public schools and roads. Many counties have much of their area, in some cases more than half, in National Forests, and this land is withdrawn from the possibility of private ownership and taxation. By the new law the loss to the counties from the withdrawal of taxable land is offset.

The business management of the National Forests is in itself a large undertaking. The business on the National Forests is destined to grow rapidly and to assume far-reaching economic importance. In the fiscal year ending June 30, 1907, approximately $\$ 1,500,000$ was received, chiefly from grazing and timber sales. The returns from timber sales alone, over $\$ 500,000$, more than doubled the returns of the

a Since the Wichita National Forest, Oklahoma, has been designated a game preserve by authority of an act of Congress (33 Stat., 614), and all agricultural land within its boundaries will soon be needed to carry out the provisions of this act, the act of June 11, 1906, permitting agricultural settlement, does not apply to that forest. 
previous year. Grazing, which formerly had been free, has brought in nearly $\$ 1,400,000$ under the permit system inaugurated in January, 1906.

The free use of timber and stone which, at the discretion of the Secretary of Agriculture, is granted to settlers and others who may not reasonably be required to purchase, as well as to school and road districts, churches, or cooperative organizations of settlers, very greatly aids the development of the regions in and near the Forests.

It is the active policy of the Forest Service to manage the National Forests upon a sound technical as well as business basis. Only improvement in the standard of the technical management can secure steady and constant increase in returns without depleting the forest. To this end careful investigation is essential. This includes special study of the habits and requirements of trees as a basis for the regulation of cutting of every kind. Special attention is given to finding new uses for species at present valueless or little used, as well as for the trees already classed as commercial and for timber killed by fire or insect attacks. Studies are made of damage by fire and the best means of preventing it, and, in cooperation with the Bureau of Entomology, of the prevention and control of insect ravages. In these and in many other ways the basis of knowledge necessary for the best forest work is being laid.

Aside from the care and perpetuation of the National Forests, the Forest Service has to do with the practical uses of forests and forest trees in the United States, especially with the commercial management of forest tracts, woodlots, and forest plantations. It undertakes such forest studies as lie beyond the power or the means of individuals to carry on unaided. It stands ready to cooperate, to the limit of its resources, with all who seek assistance in the solution of practical forest problems, particularly where such cooperation will result in setting up object lessons to serve as encouraging examples for the general benefit.

Cooperative State studies are carried on with States which request the advice of the Service. Examples of this work are the studies of forest conditions in New Hampshire, which appropriated $\$ 7,000$ toward the total cost, and California, which appropriated $\$ 25,000$. Maine, Massachusetts, Maryland, Rhode Island, Delaware, North Carolina, Kentucky, Tennessee, Missouri, and Mississippi have also called upon the Service for expert assistance.

The fruits of its more important studies are published and distributed without charge upon request, or sold at a low price by the Superintendent of Documents.

\section{ORGA IZZATION.}

The work of the Forest Service is organized under four Branches and fourteen Offices. The Office of the Forester stands at the head, and the Branches, which are Grazing, Operation, Silviculture, and Products, report to the Forester. The accompanying chart (fig. 1) shows this organization graphically. 


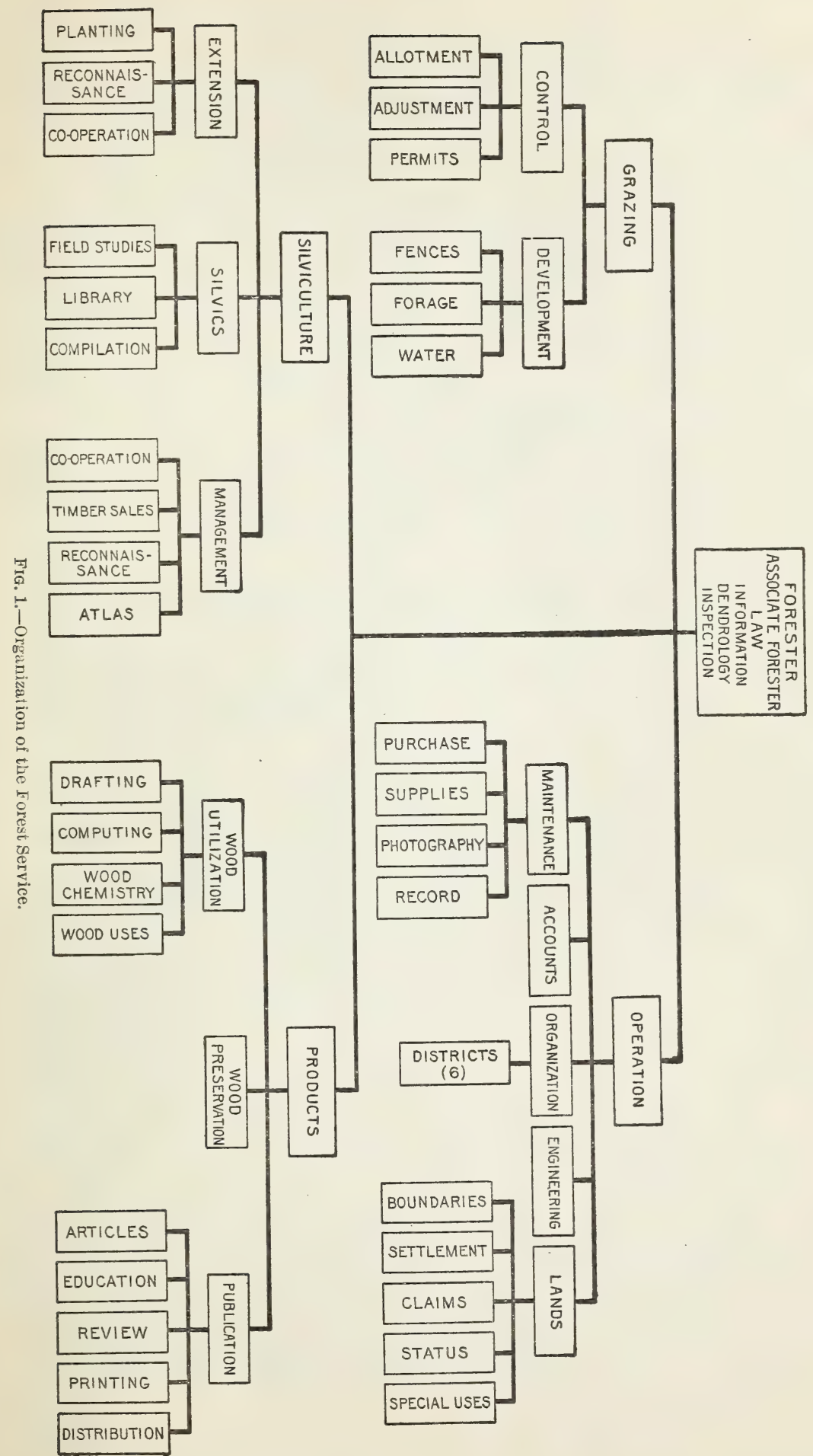

12839-No. $36-07-2$ 


\section{OFFICE OF THE FORESTER.}

The Forester is the administrative head of the Service, to whom all the offices are responsible. The Associate Forester is his chief assistant and the administrative head of the Service in the absence of the Forester.

The law officer advises the Service in legal matters, assists in the criminal prosecution of offenders against the laws and regulations which protect the National Forests and in civil suits to recover damages suffered by the United States from trespass committed upon the Forests, compiles forest laws, aids applicants in drafting forest legislation, and deals with other legal questions connected with forests, their ownership, taxation, and protection. Within proper limits his help and advice are freely open to the public.

The editor plans the lines along which the Forest Service makes known to the public the practical results of its work, answers requests for material for publication, and prepares articles upon forestry and the work of the Service.

The work of the dendrologist includes dendrological studies proper, direction of the Service's forest photograph collection, and charge of the forest exhibits prepared by the Service.

A leading branch of the dendrological studies is the making of an accurate forest map of the distribution of tree species in the United States, to show the extent, composition, and economic possibilities of our forest resources. Others of these studies concern the cedar forests of Texas, and important but little known trees indigenous to the United States, the growth of which may be profitably extended to new localities for economic purposes. Prominent among the latter are the desert pines of California. An investigation is being made of the present and probable future supply of western tanbark oak, as well as of other trees the barks of which are used to adulterate tanbark, and the tannin contents of the barks are being determined by the Bureau of Chemistry. Included also is a study of basket willows. Experimental holts are established on the Arlington Experimental Farm, near Washington, D. C. Attention is given especially to the conditions under which high-grade basket rods may be produced. Approved basket willow cuttings are distributed free each spring to applicants interested in willow culture.

An improved system of turpentining, introduced by the Service among turpentine operators, is described in Bulletin 40 and Circular 34 of the Forest Service. The system not only conserves the life of the trees much more than any previous method, but also gives a larger and better yield. Experiments now in progress seek still further saving of the trees by reducing the extent and depth of the wound 
in chipping. In connection with this investigation a study is being made, in cooperation with the chemical department of the University of North Carolina, of the characteristics of turpentines yielded by native timber pines.

A series of important publications in course of preparation will describe and illustrate the tree species of the different regions of the United States. The first of these bulletins to be ready will embrace the trees of the Pacific coast, and the second those of the Rocky Mountain States. One special use of these tree books will be the aid which they will give Forest officers on National Forests in identifying species and in acquainting themselves with their habits, growth, distribution, and other important facts.

The dendrologist also gives technical information about trees, in response to inquiries, including the identification of the wood, seeds, foliage, etc., of native and exotic trees. A large and growing correspondence evidences the public demand for such information.

The Government forest exhibits prepared for State, National, and international expositions explain what forestry is and show its application to the problems with which the Service is dealing. Through these displays much public interest is aroused and information given concerning our forests, their economic importance, and right and wrong methods of using them.

\section{INSPECTION.}

It is the policy of the Forest Service to maintain a thorough system of inspection of its own work. There are about twenty-five inspectors, charged with oversight of all the activities of the Service, both on the National Forests and elsewhere. It is the duty of the inspectors to see exactly what work is being done and how it is being done, and to advise with all those in charge of projects or having administrative authority in National Forests. They are not, however, themselves authorized to issue orders. Their reports are made directly to the Forester.

There are six inspection districts, each in charge of a chief inspector. These districts are:

District 1. Montana, northern Wyoming, and northern Idaho.

District 2. Colorado, southeastern Utah, Nebraska, South Dakota, Kansas, southern Wyoming, and southeastern Montana.

District 3. Arizona, New Mexico, and Oklahoma.

District 4. Utah, southern Idaho, eastern Nevada, western Wyoming, and northern Arizona.

District 5. California and western Nevada.

District 6. Washington, Oregon, and Alaska. [Cir. 36] 


\section{BRANCH OF GRAZING.}

The Branch of Grazing has charge of the range in National Forests. The live-stock interests in National Forests are now very great. In the past much difficulty has arisen over the equitable use of the range. The present system of charging a reasonable fee for all live stock, which was inaugurated at the beginning of 1906, has already received widespread approval among live-stock owners. By paying for the right to use the range these owners benefit both by avoiding all cause of dispute and by the protection which the Forest Service gives in consideration of the charge. Opposition to the system of fees continues only where a shortsighted policy is still prone to insist upon the immediate exploitation rather than upon the permanent and increasing development of the range. Settlements for trespass or for understatement of the number of the stock have, as a rule, been promptly made. During the first six months of 1906 the revenue from grazing was over $\$ 500,000$, and for the first five months of 1907 , over $\$ 700,000$.

Two offices, the office of control and the office of development, administer the grazing business, the former including the sections of allotment, adjustment, and permits, and the latter those of fences, forage, and water.

Among the matters which must be decided in the management of this Branch are, what number of stock shall be allowed to graze, what portions of Forests shall be open to grazing, the period during which grazing is allowed, the fees to be charged for permits, the settlement of controversies, the examination of title to private lands, the establishment of driveways for live stock, the fencing of portions of the ranges, the storage of water in tanks where water shortage prevents the utilization of good forage, settlements for damages, and the formulation of special rules to meet local conditions. By cooperation with live-stock associations through their advisory boards a constant good understanding of rights and duties is made possible between stock owners and the Forest Service.

\section{BRANCH OF OPERATION.}

\section{OFFICE OF MAINTENANCE.}

The office of maintenance exercises a general supervision over the quarters occupied by the Washington office and the supplies and office equipment of the entire Service. The work is divided into the sections of record, purchase, supplies, and photography.

The section of record has oversight of the mail, files, mailing lists, and routine matters pertaining to office administration. 
The section of purchase has charge of matters pertaining to the purchase of supplies.

The section of supplies is under the direction of the property clerk, who has the custody of instruments, equipment, furniture, and office supplies for use of the Service in Washington and in the field.

The section of photography furnishes supplies for photographic work, and carries on the processes by which the final results are shown.

\section{OFFICE OF ACCOUNTS.}

In the office of accounts are the sections of bookkeeping, disbursements, and receipts.

Appointments, promotions, furloughs, and leave without pay, and all records of annual leave of members of the Service, as well as letters of authorization, are prepared and kept in this office; income from the resources of the National Forests is recorded and forwarded to the Treasury; vouchers for salaries, services, and purchases in connection with the Service are prepared and recorded, and checks in payment are drawn and forwarded. In this office also are kept records of all expenditures under the different appropriations for the Service, of liabilities, and of the cost of all projects.

\section{OFFICE OF ORGANIZATION.}

This office has charge of the executive force on the National Forests.

For administrative purposes the National Forests are grouped into six districts, which correspond to the inspection districts. (See p. 11.) This office has direct oversight of personnel, equipment, and expenditures. It also examines all matters of an administrative character which are prepared in the other offices, and forms the central agency by which the administrative work of all branches is brought together and harmonized.

The permanent field force on the National Forests now contains the grades of chief inspector, inspector, forest supervisor, deputy forest supervisor, forest assistant, planting assistant, lumberman, forest ranger, and forest guard.

Examinations for these positions are held as required in each State and Territory in which National Forests are situated. Applicants for the positions of ranger or supervisor must be legal residents, between the ages of 21 and 40 .

The restriction as to residence is not imposed upon applicants for the forest assistant examination, for which the age requirement is 20 to 40 years.

Inspectors are appointed only from those who by their qualifications, training, and experience have gained great familiarity with

[Cir. 36] 
National Forest problems and unusual efficiency in the conduct of Forest business. Their duties are to inspect the Forests in their districts, see and report on existing conditions, recommend changes for the better in both the business and technical management and in personnel, and assist the local officers, by suggestions and advice, in all Forest matters.

Appointments to the position of forest supervisor are made by the promotion of competent forest rangers or forest assistants, when they can be found in the State or Territory in which the vacancies exist. Should there be no thoroughly satisfactory resident forest rangers or forest assistants, examinations of other applicants are held. The qualifications for the position of supervisor include all those required of rangers, as hereafter outlined, with superior technical, business, and administrative ability.

Supervisors have full charge of their Forests, plan and direct all work, have entire disposition of rangers and other assistants, and are responsible for the efficiency of the local service. Under instructions from the Forester supervisors deal with the public in all business connected with the sale of timber, the control of grazing, the issuing of permits, and the enforcement of all regulations which govern the use, protection, and occupancy of National Forests. They keep the records and accounts and conduct the correspondence and general office business of their Forests, and make reports to the Forester on all matters under their jurisdiction. Each supervisor is required to keep, at his own expense, one or more horses for his transportation in the Forest, and is allowed actual and necessary traveling expenses when away from his headquarters.

The position of forest assistant or planting assistant requires technical qualifications of high order. Forest assistants or planting assistants may be assigned to any part of the United States, and must be competent to handle technical lines of work, such as the preparation of working and planting plans, the investigation of the silvics and uses of commercial trees, the study of wood preservation, and other inrestigations requiring a trained forester. When assigned to a National Forest, such assistants are placed directly under the supervisor, from whom they receive their orders and to whom they report. They are required to own and keep horses when necessary.

Lumbermen, technical men, and others temporarily assigned to Forests are directly under the instructions of the supervisor and report to him on all Forest niatters.

To be eligible as ranger of any grade the applicant must be, first of all, thoroughly sound and able-bodied, capable of enduring hardships and of performing severe labor under trying conditions. No one nay expect to pass the examination who is not already able to take care of [Cir. 36] 
himself and his horses in regions remote from settlements and supplies. He must be able to build trails and cabins, shoot, ride, pack, and deal tactfully with all classes of people. He must know something of land surveying, estimating and scaling timber, logging, land laws, mining, and the live-stock business.

The examination of applicants is along the practical lines indicated above, and they are required to show that they can do these things by actually doing them. Where boats, saddle horses, or pack horses are necessary in the performance of their duty, rangers are required to own and maintain them. Rangers execute the work of the National Forests under the direction of the supervisor. Their duties include patrol to prevent fire and trespassing; estimating, surveying, and marking timber; the supervision of cuttings, and other similar work. They issue minor permits, build cabins and trails, enforce grazing restrictions, investigate claims, report on applications, and arrest for violation of Forest laws and regulations. In the absence of the supervisor, charge of the Forest falls on one of the rangers or assistants.

Deputy rangers and assistant rangers have charge of definite districts, to which they are assigned by the supervisor. They supervise forest guards stationed within their districts, and may also be given temporary laborers when necessary.

In addition to the permanent classified force upon the Forests, forest guards receiving from $\$ 60$ to $\$ 75$ per month are employed to fill vacancies for which the eligible list is inadequate or to supply additional men for patrol and protective work for not over six months at a time. Forest guards have the powers and duties of assistant forest rangers.

\section{OFFICE OF ENGINEERING.}

Many roads, trails, telephone lines, cabins, bridges, fences, fire lines, and other improvements of a permanent nature are necessary in order to give the National Forests better protection and to facilitate Forest work. For making these improvements Congress at its last session granted the Forest Service a fund of $\$ 500,000$, which will be used during the next year entirely for this purpose.

The office of engineering has charge of these improvements and also has general supervision of all engineering work, or work of a permanent nature, constructed by individuals or corporations on the different National Forests. Under this head are the large power plants being erected in the western country, among them some with a development of more than 50,000 horsepower. Canals, pipe lines, flumes, reservoirs, dams, etc., are among the other classes of work that will be taken care of by the office. This general supervision is being undertaken not only to protect the interests of the Forest Service, but [Cir. 36] 
also to protect the interests of the various settlers and ranchmen who occupy land in or adjoining the National Forests.

This office has charge of the meters installed by the different electrical companies and the inspection of their plants in connection with the conservation charge made by the Forest Service.

On the larger pieces of work an experienced man, either an engineer or a man experienced in that particular line of work, is detailed to the forest supervisor to assist in the construction. The regular force on the National Forests is large enough to take care of the routine work only, and it is necessary that additional labor be employed in special cases.

\section{OFFICE OF LANDS.}

The office of lands deals with questions involving the validity of claims asserted under the public land laws, applications for permits for special use of the resources of the National Forests, changes in the boundaries of Forests, and the examination of lands applied for under the act of June 11, 1906, for agricultural settlement. The utmost encouragement is given to bona fide claims for mineral and agricultural lands. The miner is protected and assisted in the exploitation of his claim and is given free use of timber for firewood and building purposes. It is for the protection of the miner and the farmer that only those seeking title in good faith are permitted to enjoy the products of the Forest, while others are treated as trespassers.

The section of boundaries deals with the examination of lands for proposed National Forests or additions to and eliminations from existing Forests. The act of March 3, 1891 (26 Stat. L., 1095), provides that the President may set aside, by proclamation, in any public land State or Territory lands wholly or in part covered with timber or undergrowth as National Forests. Under the authority of this act practically all of the existing National Forests have been created. Congress may, however, take action, and has done so in a few cases. In an amendment to the agricultural appropriation act, approved March 4, 1907, it is provided that "hereafter no forest reserve shall be created, nor shall any addition be made to one heretofore created within the limits of the States of Oregon, Washington, Idaho, Montana, Colorado, or Wyoming, except by act of Congress." The power of the President to create or enlarge National Forests in other States and the Territories is unimpaired.

In 1903 the need of better choice of Forest boundaries led to the establishment of the section of boundaries, comprising a force of trained men devoted exclusively to boundary examinations under a uniform and complete system of field study and reports. The results were satisfactory and the system remains in effect. Before any new 
National Forest is created or any change is made in the boundary of an existing Forest a member of the Forest Service familiar with the work and with western conditions makes a careful investigation, not only of the lands but also of the interests involved. The claims of all industries and classes of residents are weighed, in order that no injustice shall be done.

The region is carefully mapped and described, and the boundary of the Forest is drawn to include only lands suitable for forest purposes. Possible agricultural areas are always excluded unless they are small and isolated. The temporary withdrawal of lands unsuitable for forest purposes is sometimes necessary pending the examination of the area for a proposed Forest. In all cases, however, such lands are released as a matter of course when the boundaries have been drawn.

The section of settlement deals with agricultural settlement in the National Forests. When the boundary lines of Forests are established every effort is made to embrace no land that is more valuable for agriculture than for forest purposes, but a number of small agricultural tracts are unavoidably included within their limits. In order to permit all the land in the Forests to be brought to its highest development the Forest Service advocated the passage of the act of June 11, 1906. In the year following the approval of the law three thousand five bundred applications were received for the examination ard listing of lands under this act. Forest officers were sent to determine the char. acter of the lands, and reports upon tracts for which there were 900 applicants have been received and acted upon. For a great many of these areas conflicting applications were received. More than 48,000 acres of land, listed with the Secretary of the Interior will be declared open to settlement and entry.

The Forest officers making these examinations are especially trained for this work and are familiar with the needs and value of the lands for timber and agriculture. They are of the force which makes boundary examinations.

Although these applications are still being received, and it is estimated that 2,000 more persons will apply, it is believed that a large majority of the tracts applied for will be reported upon during the present field season.

The establishment of a National Forest does not affect or place at a disadvantage persons already having valid claims under the public land laws or legal title to lands within the Forest. Such persons are free to occupy and enjoy their holdings and perfect their claims, provided only that they do not interfere with National Forest interests. After a National Forest is established mining claims can be initiated as elsewhere.

The Forest Service endeavors to protect valid claims in National Forests and make the Forest contribute to their development, but it is 12839-No. 36-07-3 
the duty of Forest officers to report to the Forester illegal holding's. The Forester, on the basis of reports made to him by Forest officers on unperfected claims in National Forests, recommends to the Commissioner of the General Land Office the granting or withholding of patents to the claims.

As a result of investigation by Forest officers, claimants affected have roluntarily relinquished or abandoned illegal claims, and the lands have thus been restored to the National Forests and brought within the field of public use.

The Serrice takes the utmost care to prerent injustice to mining claimants through reports by Forest officers. Where doubt exists as to a raluable discorery of mineral, the Forester directs special examination of the claim by a geologist detailed for the purpose by the United States Geological Survey.

Claims are carefully considered and recommended for patent, except where careful inrestigation demonstrates them to be illegal or fraudulent. Persons actually occupying and using, in National Forests, land for a home or for purposes of business, where the conditions preclude their acquiring title to the land, under an 5 law, are permitted to continue their occupancy under a permit so long as they do not interfere with National Forest interests.

In accordance with the policy of the Serrice to encourage and assist legitimate enterprises throughout the National Forests, special-use permits are issued for all lawful purposes not inconsistent with Forest interests. The section of special uses has charge of this work. To facilitate the transactions and more effectually meet local conditions and demands, the authority to issue such permits, with few exceptions, is delegated to local forest supervisors.

The commercial and industrial interests in the National Forests are now rely great, and the enterprises conducted on National Forest lands under special use permits represent practically all branches of activity. The following are the more usual purposes for which these permits are issued: Residences, farms, pastures, drift fences, corrals, apiaries, dairies, schools, churches, roads, trails, telephone and telegraph lines, stores. mills, factories, lime and charcoal kilns, hotels, stage stations, sanitariums, camps, summer resorts, wharres, miners' and prospectors' cabins, windmills, dipping rats, tanks, dams, reservoirs, water conduits of all kinds, power houses, power-transmission lines, aerial tramways and cable conveyors, railroads, tramroads, and the purchase of sand, stone, clay, grarel, hay, and other National Forest products, except timber.

The charges made for permits are hased upon the value that is actually furnished to the permittees, including advantageous location and otber indirect benefits, and not directly upon the profits or the magnitude of the business which is to be carried on.

[Cir. 36] 


\section{BRANCH OF SILVICULTURE.}

\section{OFFICE OF EXTENSION.}

The work of the office of extension falls under two main heads: Administrative control of all forest planting within the National Forests and advisory assistance to private landowners.

The section of reconnaissance has charge of special and regional studies of forest planting on which the work of the sections of planting and cooperation is based. Studies of conditions affecting forest planting in different States, investigations of the possibilities of planting on irrigated lands, and preliminary reconnaissance in National Forests under the direction of the supervisor, followed by the preparation of general plans for forest planting, comprise the principal field of work.

The section of planting deals with all phases of forest planting within the National Forests. In the past two important problems have received special attention: (1) The reforesting of denuded watersheds where planting is needed in order to control and regulate the flow of streams directly supplying cities and towns; (2) planting within the treeless National Forests in the Middle West to provide for timber in the future and to serve as an object lesson to the people.

The trees used in planting are grown at eight Government nurseries in the following National Forests: San Gabriel, Santa Barbara, Gila, Dismal River, Pikes Peak, Salt Lake, Pecos, and Lincoln. The combined area of seed beds at the eight stations is 11 acres. They now contain over 5,000,000 trees, from 1 to 3 years old. The seed sown in 1907 should produce not less than 4,000,000 trees, giving a total of over $9,000,000$ in 1908 .

The planting stations are so situated that in addition to providing plant material for local use they also serve as distributing points for other National Forests.

The preliminary stage of forest planting within the National Forests is now past, and several of the planting stations have this year produced trees of sufficient size to plant directly on the permanent site. About 700,000 trees were planted during the winter and spring of 1907, the greater part in the Dismal River, Niobrara, North Platte, San Gabriel, Santa Barbara, and Pikes Peak National Forests. At the nursery in the Dismal River National Forest more stock has reached an age suitable for planting than at the other stations. This nursery contains approximately $2,500,000$ trees. In the spring of 1908 there will be about $1,000,000$ trees ready for planting in the sandhills. The species largely in use up to this time in planting within this Forest are western yellow pine and jack pine. Other species, chiefly Scotch pine, Norway pine, and Douglas fir, are being tested in the nursery and in experimental plantations. 
The Pasadena and San Marcos stations are heing used as distributing points for some of the southern California National Forests. These two stations hare a combined capacity of about 600,000 trees anuually. The species which are most successful are knobcone pine, Coulter pine, Jeffrey pine. Canary Island pine, bigcone spruce, incense cedar, and deodar cedar. Experimental planting of eucalypts in the foothills has recently been begun and trees are now being grown for this purpose. The field planting done in the Santa Barbara and San Gabriel National Forests this year has been more successful than that of any previous year.

The Fort Barard Planting Station, near the Gila National Forest, this spring began producing stock for planting. The nursery in the Pikes Peak Forest will produce a considerable quantity of trees in the spring of 1908. The other stations hare not yet been in operation sufficiently long to furnish stock for field planting:

In 1906 plans were made for the establishment of small nurseries at rangers' headquarters in the National Forests. Many nursery sites were selected and the preliminary work has already been completed at some of these. The primary object was to train Forest officers in nursery and planting work and at the same time secure a considerable stock of seedlings for local use within the Forests where the need is great. The stock grown at rangers' nurseries will be of much ralue in experimental planting to determine the best methods and species to be used in the future. The results obtained in rangers' nurseries within a National Forest will give a practical basis for the selection of one or two sites where the work may be centralized, and then more extensive nursery and planting operations can be carried out.

Under the provisions of Circular 22 the section of cooperation provides two forms of assistance to landowners: (1) Advice for forest planting in all the principal regions of economic planting, which can usually be given free of cost by means of publications and an advisory letter, together with lists of dealers who quote plant material of the species recommended: (2) for tracts in regions where a detailed study has not been made. and which presents problems of great economic importance and high experimental or educational ralue. an examination of the land may be made and a planting plan prepared by a representatire of the Forest Service. The cost of a planting plan is based on the necessary expense on the ground and must usually be paid by the landowner. In exceptional cases the cost may be shared or borne entirely by the Service, in consideration of the special value of the work as an example in practical forestry.

Applications for assistance in tree planting should be made to the Forester, U. S. Departmeut of Agriculture, and should specify the location and character of the proposed planting sites and the object of planting. 


\section{OFFICE OF SILVICS.}

The office of silvics deals mainly with the general scientific problems underlying the practical management of National and private forests. It investigates the factors controlling the distribution of forests and forest trees throughout the United States, the relation of forests to stream flow and climate, and the conditions under which natural regeneration of eut-over, burned-over, or otherwise denuded areas takes place. It studies the different requirements which commercial or otherwise important species have upon climate, moisture, soil, and light, and publishes the results in the form of monographs upon species. It establishes experimental areas to determine the effect of grazing upon reproduction, of thinnings upon the young growth of the stand, of the removal of leaf litter upon the growth of trees, and so on. Besides obtaining new data through field studies, it also brings together and organizes, in the interest of systematic knowledge, all information on the habits and behavior of trees in the forest already gathered by past studies of the Forest Service or accessible in other sources. Thus, there are now compiled data for 167 species. The range, rate of growth, light, moisture and soil requirements, and habit in pure stands and in mixture with other species are among the subjects treated. At the same time notes were gathered as to the silvical conditions of 60 National Forests.

Closely connected with the compilation of all available information regarding the life history of forest trees and forest conditions is the library of the Forest Service. This contains 10,900 books and pamphlets on forestry and allied subjects, 27,500 photographs of trees and forest conditions, and 4,000 lantern slides. The library forms a most important working tool for all members of the Forest Service in the preparation of reports and bulletins, and is of greatest help in disseminating correct ideas regarding forestry among the people. The photographic collection is extensively used by educators, newspaper and magazine writers, etc. When a request for photographs is received a selection covering the species desired is made and duplicates are then prepared from the original negatives and sent to the person making the request, the charge being practically the cost of printing. There is a large and increasing demand for the loan of lantern slides for illustrating lectures on forestry. During the last fiscal year about 2,500 slides were loaned.

Branch libraries are being established in the offices of supervisors on the National Forests as rapidly as books can be secured for them. Already 117 such libraries have been started.

\section{OFFICE OF MANAGEMENT.}

This office deals with the problems of management offered by existing forests, whether these are on the National Forests or on tracts [Cir. 36] 
belonging to some State, company, or individual. Its work is divided, broadly, between the National Forests and cooperative projects.

The section of timber sales has oversight of the disposal of timber on the National Forests. Working plans are prepared as far as possible in advance of all sales, and in every case sales are carried on under contracts which provide for the right silvical condition of the forest, careful logging methods, and safeguards against fire. An important provision in all sales of large amount limits the period of the sale, the longest contract being for five years, and requires that each year a definite quantity be removed. In this way speculation in National Forest timber is prevented. Since the transfer of the Forests to the Forest Service two rears ago business methods in the disposal of timber have been simplified and the rolume of sales has greatly increased. In the fiscal year ending June 30, 1907, returns from this source exceeded $\$ 600,000$.

The section of reconnaissance studies the relation of supply and demand of the timber resources of the National Forests. An important part of its work is the location and rough estimating of tracts of timber on the National Forests in advance of actual application for the purchase of the timber, in order that information may be at hand whenever anyone does wish to purchase. It also investigates the future supply of timber needed for special purposes in different localities.

The Forest Atlas combines all maps of the National Forests on a uniform scale and with uniform symbols to designate the different species of trees, topographic features, and culture. These maps are of the greatest value to all branches of the Forest Service for reference, and are especially useful for keeping a graphic record of present and past timber sales and of the permanent improvements on the National Forests.

The section of cooperation has the supervision of work through which the Service gives assistance to private owners in the management of their forest lands.

Private owners of timberlands, large or small, may secure the aid of the Forest Service in the care of their lands under a plan of cooperation fully outlined in Circular 21. Any owner who wishes to learn whether forestry might be profitable to him may apply to the Forest Service for a working plan. An agent of the Service is then sent to examine the forest. If the piece of woodland is small, as in farm woodlots, and management is practicable, a plan is outlined on the spot and carefully explained to the owner. In the case of large tracts the preparation of a working plan requires a more prolonged study on the ground. The agent sent to examine the tract therefore first finds out whether a sufficiently good opening for paying management exists to justify the outlay. His report is submitted to the owner, with an estimate of the cost of preparing the plan if a plan is found desirable. 
If the owner desires the working plan, a force of men is sent to collect the necessary data. A thorough examination of the tract is made both from the forester's and from the lumberman's points of view. The merchantable and immature trees upon sample strips are counted and their diameter measured, and from these data the stand on the whole tract is calculated. Volume and rate of growth are ascertained for the important species through tree analyses-that is, through measurements of felled trees and counts of their annual rings. Studies are made of reproduction, of the danger from fire, grazing, and insect attack, and of the best means of preventing such injuries. Market and transportation facilities are carefully investigated, and the yield of timber and the character and distribution of the forest are mapped.

When these facts have been collected they are worked up into the plan, which takes into account the special needs or purpose of the owner, as, for instance, to secure permanent supplies of mining timbers, to maintain a game preserve, or to protect a watershed. The recommendations in the plan enable the owner to derive from the forest the fullest and most permanent revenue which is consistent with his special requirements.

The chief object of this work is to get forestry into actual practice with successful results. When necessary, therefore, a representative of the Service visits the owner again, confers with him on the details of the plan, and at his expense assists, if he desires it, in the actual work of putting the recommendations in force. Subsequent advice, if needed, can be secured by the owner on the same terms. But the Forest Service in all cases preserves its interest in the success of the methods which it has suggested and sends one of its experts about once in two years to inspect the progress of management and to make any fresh suggestions which the lapse of time or the owner's desire may have made necessary or advisable.

\section{BRANCH OF PRODUCTS.}

\section{OFFICE OF WOOD UTILIZATION.}

The work of the office of wood utilization is to further economy in the use of materials which come from the forest. The office comprises the four sections of drafting, computing, wood chemistry, and wood uses.

The work of the section of drafting includes the mapping of the many conditions which must be taken into consideration in locating and administering the National Forests, such as the legal status of lands, natural land classification, forest classification, water supply, and topography. The section makes maps which form the basis of the proclamations setting aside the National Forests, maps which record the results of the investigations of the Service, and working[Cir. 36] 
plan maps and planting-plan maps for the cooperative and administratire work. It includes, further. plans and working drawings of apparatus for logging. preserring timber. and timber testing; the miscellaneous illustrations, maps. diagrams. and tables for the publications of the Serrice, and the determination of areas from maps.

The section also has the custods of original maps and map data, and is charged with the responsibility for the development and application of srstems of mapping the data collected br the Forest Service.

The computing section is charged with the compilation of all forest tables and the keeping of a file of forest tables. In this file are kept all reliable tables of stand, yield, growth, and form for our many species of forest trees. Copies of any table may be secured on application. The compiling, editing, and rerising of these tables for publication is in progress, and circulars containing the more useful tables will shortly appear. The rolume tables are the feature of the work and represent a beginning of American rolume tables. Tables of lodgepole pine and western rellow pine are the first to be completed. These will be followed by tables for Douglas fir and other species important in the National Forests. The circulars corering all the species of a region are later to be combined with a chapter on methods of taking forest measurements and of construction of tables. The plan embraces three general regional compilations, riz, the western, the southern, and the northern.

This section also computes and tabulates data taken by other offices of the Serrice.

The section of wood chemistry handles the chemical problems connected with the utilization of wood products. Work in progress includes the analrsis of wood preserratives and of treated timbers. test of the suitability of various species of wood for paper pulp, a study of mood distillation, and an inrestigation of the chemical changes inrolred in water seasoning. A thorough study of the best methods of analyzing coal-tar creosote, including a determination of the properties of creosotes distilled from other kinds of tar. is nearing completion. Work on the preservative ralue of different fractions of coaltar creosote and of other creosotes is under way. The composition of turpentines obtained by mood distillation is being studied to secure the necessary data for establishing standard grades of this product. A special laboratory for the studr of wood pulps, which includes a small sulphite plant, has been, equipped to determine the paper-making possibilities of many species of American woods.

The section of mood uses studies the supply, markets, properties, and uses of lumber and other forest products, and gires especial attention to the characteristics of woods which fit them for specific purposes. The principal lines of work carried on are grouped under special studies and timber tests. To meet an urgent need for an [Cir. 36] 
annual statement of the amount of lumber and other forest products used, statistics are gathered and published in cooperation with the Bureau of the Census and the National Lumber Manufacturers' Association. The grading specifications under which lumber is manufactured by the various associations have been published. Some studies of special uses for woods have taken form in published reports upon cooperage woods, vehicle and implement woods, box woods, and methods of kiln-drying hardwoods.

The timber tests are designed to secure a better knowledge of the comparative strength of timbers under various conditions, to add to the list of commercial species suitable for construction purposes, and to promote economy in the manufacture and use of timbers. The structural value of rapidly grown timber, and the effect of preservatives on the strength of timber, are examples of the subjects studied. Other studies aim at the collection of data for drawing up more accurate and satisfactory rules for the grading of structural timbers, the supplying of information on the properties of unfamiliar woods, and the placing of the technique of timber testing on a scientific basis.

The Forest Service conducts a series of laboratory experiments, under a trained staff of testing engineers, in cooperation with Yale and Purdue universities and the universities of the States of California, Washington, and Oregon. A bulletin has been printed on the effect of moisture on the strength and stiffness of wood. Preliminary tests to determine the mechanical properties of Douglas fir, loblolly, longleaf, and Norway pines, western hemlock, and tamarack have been made.

\section{OFFICE OF WOOD PRESERVATION.}

In the office of wood preservation experiments are carried on to determine economical means of handling and treating wood to insure its greatest service. Practically all work is done in cooperation with persons or companies directly interested in the results. In cooperation with railroad companies improved methods have been found of treating with preservatives cross-ties of Douglas fir, lodgepole pine, western yellow pine, red oak, loblolly pine, hemlock, tamarack, western larch, and western hemlock. Test tracks have been laid containing untreated ties and ties subjected to different methods of treatment, in order to study their relative values under actual conditions of exposure. Different forms of metal and wooden tie plates have been employed with both screw and common spikes, in order to determine the most efficient rail fastening for softwood ties. Wooden tie plates have been used with both treated and untreated ties.

Cooperative studies with telephone and telegraph companies have led to the adoption of open-tank methods of treatment for certain classes of material. Test lines have been established in which green, seasoned, and treated poles are placed successively to determine the

[Cir. 36] 
lasting qualities of each sort through a period of years. As a result of studies in the grading, seasoning, and treating of cross-arms, a more uniform, efficient, and economical treatment for this and similar classes of material has been obtained. Successful results in the opentank treatment of loblolly pine mine props have shown that pressure is not necessary to secure a satisfactory penetration of the preserving fluid, prorided that the material has been properly seasoned. Experiments to prore the feasibility of treating seasoned posts in the open tank hare also reached a successful conclusion. Projects are planned to utilize dead and down timber in the National Forests by open-tank treatment with preservatives.

Cooperative investigations have been carried on with cities to determine the kinds of woods suitable for paring blocks, and methods of treating them; experimental parements have been laid, containing various kinds of wood treated in different ways.

A study has been made of the timbers employed as piling in salt water, and the methods in use to protect them from the attack of marine wood borers. In order to promote the preservative treatment of wood, the Service will, wherever possible, cooperate with those confronted by the important problems of prerenting decay of timber on land and preventing attacks of marine borers in salt water.

\section{OFFICE OF PUBLICATION.}

In general this office has charge of all the editorial and educational work of the Service, including the technical and literary review of its publications. This work is distributed among fire sections, as follows:

The section of articles publishes a monthly field program of projects under way, and prepares special articles upon the subject of forestry in general and the work of the Service in particular.

The section of education is charged with the broad work of bringing home the lessons of forestry through erery arailable educational channel, such as lectures and addresses, school instruction, and the propaganda of ciric, industrial, and other associations.

The section of review critically examines the form and substance of proposed publications.

The section of printing sees through the press all the forms and manuscripts printed by the Service, prepares printing requests, and keeps all necessary record of Service printing work.

The section of distribution has charge of the circulation of all Forest Service publications. It decides, through a familiarity with the manuscript, as to the distribution which shall be given each one. It directs, and is responsible for, the plans under which the Service mailing lists are made up and maintained, and supervises the general policy which covers the filling of requests for publications.

[Cir. 36] 


\section{CLASSified List OF PUBLICATIONS AND gUIDE TO THEIR CONTENTS.}

Application for any of the publications named in the following list, except those marked (*), may be made to The Forester, United States Department of Agriculture, Washington, D. C.

A star (*)'indicates that there is no supply at the disposal of the Forest Service and that the document can be obtained only by purchase. Remittance should be made by postal money order (stamps not accepted) directly to the Superintendent of Documents, Government Printing Office, Washington, D. C.

\section{GENERAL FOREST SUBJECTS.}

* Bulletin 24: A Primer of Forestry, in two parts. Part I-The Forest. Price, 35 cents. Part II-Practical Forestry. Price, 30 cents.

The Primer, written by Gifford Pinchot, Forester, deals with the facts on which forestry is based. It is designed to place in the hands of the average reader just what he ought to know about trees in the forest. systems of forest management, forest influences, and the history of forestry and its status here and abroad. Numerous illustrations explain the text.

Farmers' Bulletin 173: A Primer of Forestry (paper).

A reprint of Bulletin 24, Part I.

Circular 23 (Third Revision): Suggestions to Prospective Forest Students.

Circular 35: Forest Preservation and National Prosperity.

Extracts from addresses delivered before the American Forest Congress at Washington, D. C., in January, 1905, including the address of the President of the United States and that of the Secretary of Agriculture.

Circular 96: Arbor Day.

Suggestions for bringing home to children the simpler truths of forestry, emphasizing the use and value of the forest tree in the life of the nation.

Annual Reports of the Forester for 1892, 1901, 1902. 1903, 1904, 1905, and 1906.

Extracts from Yearbooks of the Department of Agriculture:

No. 143: Notes on Some Forest Problems (1898).

No. 406: Progress of Forestry in 1905 (1905).

No. 439: Progress of Forestry in 1906 (1906).

\section{NATIONAL FORESTS.}

The Use of the National Forests.

A clear exposition of the value and objects of the National Forests, with practical directions for their use by the public.

The Use Book: Regulations and Instructions for the Use of the National Forests.

An outline of the history of the National Forest policy, followed by the regulations issued by the Secretary of Agriculture on July 1. 1907, governing the administration of the Forests, with instructions to Forest officers. A compilation of the laws on which the regulations are based is appended.

Bulletin 54: The Luquillo Forest Reserve. Porto Rico.

An illustrated description of this tropical forest and its most valuable species of trees.

[Cir. 36] 
FOREST MANAGEMENT.

* Bulletin 26: Practical Forestry in the Adirondacks. Price, 15 cents.

An account of the general conditions which govern forest management in the Adirondack forest region, and a statement of the work done and the results accomplished there up to July, 1899, in cooperation with the Forest Service (then the Division of Forestry). The two working plans discussed were, with one exception, the first examples of the application of scientific forestry to large holdings in the United States.

Bulletin 30: A Forest Working Plan for Township 40, Hamilton County, N. Y.

The working plan given in this bulletin was made at the request of the forest, fish, and game commission of the State of New York, and marks the first instance of cooperation between the Forest Service (then the Division of Forestry) and the government of a State. This contains also the first detailed study of a problem in logging by a practical lumberman to be published by the Service. Included in the volume is "A discussion of conservative lumbering and the water supply," by Frederick $\mathrm{H}$. Newell, now the head of the United States Reclamation Service.

* Bulletin 32: A Working Plan for Forest Lands near Pine Bluff, Arkansas. Price, 15 cents.

Prepared in cooperation with a lumber company owning about 100,000 acres of land, about 85 per cent of the total stand on which is loblolly and shortleaf pine. This plan was adopted by the company.

* Bulletin 39: Conservative Lumbering at Sewanee, Tennessee. Price, 15 cents.

Prepared for the management of the forest owned by The University of the South, comprising about 7,255 acres of hardwoods. The application of this plan has proved highly profitable to the university.

* Bulletin 43: A Working Plan for Forest Lands in Hampton and Beaufort Counties, South Carolina. Price, 15 cents.

Prepared in cooperation with the Okeetee Gun Club for a tract of about 60,000 acres on which the stand is principally longleaf, loblolly, and Cuban pine and cypress.

* Bulletin 56: A Working Plan for Forest Lands in Berkeley County, South Carolina. Price, 10 cents.

Prepared in cooperation with a lumber company controlling about 44,000 acres of loblolly pine, longleaf pine, and cypress forest lands. This plan is now being executed by a forester in the employ of the company with extremely satisfactory results.

Bulletin 60: Report on an Examination of a Forest Tract in Western North Carolina.

* Bulletin 68: A Working Plan for Forest Lands in Central Alabama. Price, 10 cents.

This plan, which was adopted by the company for which it was prepared and is now in operation, is an example of what forestry promises the owner of longleaf pine, and what it involves. It includes studies of the forest and of lumbering methods, a discussion of the proper diameter limit in cutting, and recommendations for such a treatment of the present crop as will lead to the production of future crops.

Circular 21 (Fifth Revision): Practical Assistance to Farmers, Lumbermen, and Other Owners of Forest Lands.

Circular 113: Use of Dead Timber on the National Forests.

Extracts from Yearbooks of the Department of Agriculture:

No. 187: Practice of Forestry by Private Owners (1899).

No. 249: A Working Plan for Southern Hardwoods and Its Results (1901).

[Cir. 36] 
CARE OF THE WOODLOT.

Bulletin 42: The Woodlot.

A handbook for the use of owners of woodlands in southern New England, prepared with the object of enabling them, by observation and practice in the woods, to handle their property to the best advantage. A general discussion of woodlot management, illustrated by diagrams, widens the application of the instructions to other similar regions.

\section{COMMERCIAL TREE STUDIES.}

* Bulletin 13: Timber Pines of the Southern United States. Price, 35 cents.

A study of the commercial values of the southern pines. It contains many facts relative to the qualities of wood of the different species, as well as a study of the manner of growth of the trees.

* Bulletin 31: Notes on the Red Cedar. Price, 10 cents.

A collection of observations of the manner and rate of growth of this valuable wood.

* Bulletin 33: The Western Hemlock. Price, 20 cents.

A careful study of one of the common species of the Pacific coast, which until within the last few years was entirely ignored and wasted. The bulletin shows that the western hemlock is a distinctly valuable wood, a fact that is now beginning to be recognized.

\section{Bulletin 37: The Hardy Catalpa.}

A careful study of the rate and manner of growth of this much discussed tree. Many facts of importance are brought out and several mistaken ideas corrected.

Bulletin 38: The Redwood.

A brief preliminary study of one of the most remarkable trees in the world. Its manner of reproduction, rate of growth, and great commercial value are made clearly apparent.

*Bulletin 53: Chestnut in Southern Maryland. Price, 10 cents.

A study in a restricted locality of the habits, requirements, rate of growth, and manner of reproduction of chestnut, containing valuable information as to the capacity of the tree to produce ties and poles, of practical interest to growers of chestnut generally.

*Bulletin 58: The Red Gum (revised edition). Price, 5 cents.

In two parts; the first dealing with the range and silvical qualities of the tree and with commercial uses of gum lumber, the second with the mechanical properties of the wood.

\section{Bulletin 64: Loblolly Pine in Eastern Texas.}

A careful study of one of the valuable Southern pines, especially in relation to its use for tie timbers. The investigation was limited to eastern Texas, but many of the facts and conclusions may be applied to wider areas. The tree is common in most parts of the South, and grows vigorously on abandoned fields.

*Bulletin 69: Sugar Pine and Western Yellow Pine in California. Price, 10 cents.

A study of the range, distribution, silvical and silvicultural characteristics, commercial value, and treatment under forest management of two of the most important and valuable commercial trees of California. Its conclusions are that conservative management of sugar pine and yellow pine is practicable; that fire, the greatest obstacle to securing future crops, can be prevented at reasonable cost; and that under effective protection, and with a sufficient number of seed trees left in lumbering, natural reproduction will perpetuate the forest.

Circular 102: The Production of Red Cedar for Pencil Wood.

A study of the commercial uses of red cedar, with figures on the returns to be expected from planting for posts and pencil wood, cutting at different ages for these two classes of material.

[Cir. 36] 


\section{Circular 105: White Oak in the Southern Appalachians.}

Giving the main facts concerning the growth and supply of white oak in the region where most of it is produced, and discussing the prospects of meeting future demands for the wood, which leads all hardwoods, with an annual cut of two billion feet of lumber and over half of the ninety million cross-ties used each year.

\section{FOREST STUDIES.}

\section{Bulletin 47: Forest Resources of Texas.}

A comprehensive study of the forests of Texas, their extent, composition, and economic importance. The types of forest characteristic of different regions are described, their relation to physiography and climate is considered, and suggestions toward a wise State policy are discussed.

\section{*Bulletin 48: The Forests of Hawaii. Price, 10 cents.}

A study made at the request of the Hawaiian Board of Commissioners of Agriculture and Forestry. The report outlines a forest policy for the islands, which has been adopted and put into effect.

\section{Bulletin 55: Forest Conditions of Northern New Hampshire.}

A study made in cooperation with the State of New Hampshire, which appropriated $\$ 5,000$ for the purpose. A study of forest conditions in southern New Hampshire, now in progress, will complete the work.

\section{*Bulletin 66: Forest Belts of Western Kansas and Nebraska. Price, 10 cents.}

This report deals with forest conditions in the western portions of Kansas and Nebraska. It includes a comprehensive study of the present forest growth of the region and of the factors which tend to prevent its increase. The conclusion reached is that the present forests are much more restricted in area and are poorer in character than they need be, and practical suggestions are given for their extension.

\section{FOREST BOTANICAL AND DENDROLOGICAL STUDIES.}

*Bulletin 17: Check List of the Forest Trees of the United States. Price, 15 cents.

Giving the common and scientific names of each species, together with their geographical distribution.

* Bulletin 28: A Short Account of the Big Trees of California. Price, 15 cents.

An account of the location and character of the Big Tree groves. The possibility of maintaining them through forest protection is pointed out.

\section{Bulletin 40: A New Method of Turpentine Orcharding.}

An account of the naval-stores industry in the Southern States, in which the old methods of turpentine orcharding are described and the new "cup and gutter" system is recommended as more economical. The successful operation of the cup and gutter system is described and its results are compared with those of the older box method.

\section{Circular 34: Practical Results of the Cup and Gutter System of Turpentining.}

Showing the gains effected by the system recommended in the preceding bulletin.

* Bulletin 46: The Basket Willow. Price, 15 cents.

An account of willow culture, here and abroad, with suggestions for improvements in cultural mothods. An account of the insects injurious to basket willow and statistics showing the production and consumption of willow in the United States are added. 
* Bulletin 59: The Maple Sugar Industry. Price, 5 cents.

A complete account of old and new methods of maple-sugar manufacture, giving directions for handling the maple-sugar grove and statistics showing the extent and growth of the industry since 1850 .

Farmers' Bulletin 252: Maple Sugar and Sirup.

A brief presentation of the material used in the preceding bulletin.

\section{FOREST EXTENSION AND REPLACEMENT.}

*Bulletin 29: The Forest Nursery. Price, 10 cents.

Instructions for the collection of tree seeds and the propagation of seedlings, with other information of value to tree planters.

* Bulletin 45: The Planting of White Pine in New England. Price, 20 cents.

An account of existing white-pine plantations in this region, and a discussion of the conditions under which commerial or protective plantations may be successfully made.

* Bulletin 52: Forest Planting in Western Kansas. Price, 10 cents.

An investigation for the purpose of determining the kinds of forest trees best adapted to western Kansas and the cultural methods which have proved most successful.

* Bulletin 63: The Natural Replacement of White Pine on Old Fields in New England.

Price, 10 cents.

A description of the manner in which pastures and cut-over lands in this region tend to encourage the second growth of white pine; a discussion of the growth, reproductive power, and value of white-pine groves and woodlots; a consideration of the best means of encouraging natural replacement of white pine and of supplementing it with artificial replacement, and a statement of the profits which may be derived from the culture of white pine.

* Bulletin 65: Advice for Forest Planter's in Oklahoma and Adjacent Regions. Price, 5 cents.

This discusses in detail the forest-supporting capacity of Oklahoma and portions of Indian Territory, Kansas, Colorado, Texas, and New Mexico, and gives practical directions for the establishment and care of forest plantations on the prairies and plains, with several planting plans for windbreaks and farm woodlots in various situations.

Circular 22 (Fifth Revision): Practical Assistance to Tree Planters.

Circular 37: Forest Planting in the Sand-Hill Region of Nebraska.

Circular 41: Forest Planting on Coal Lands in Western Pennsylvania.

Circular 45: Forest Extension in Eastern Nebraska.

Circular 81: Forest Planting in Illinois.

Circular 99: Suggestions for Forest Planting on the Semi-Arid Plains.

Circular 100: Suggestions for Forest Planting in the Northeastern and Lake States.

Circular 109: Forest Planting in the North Platte and South Platte Valleys.

A discussion of the choice of forest trees for planting in the region, with special reference to the purpose of plantations, the soil and site. and the best spacing and proper care of the trees.

Extracts from Yearbooks of the Department of Agriculture:

No. 212: Forest Extension in the Middle West (1900).

No. 270: Practicability of Forest Planting in the United States (1902).

No. 376: How to Grow Young Trees for Forest Planting (1905).

Farmers' Bulletin 134: Tree Planting on Rural School Grounds. [Cri. 36] 
Farmers' Bulletin 228: Forest Planting and Farm Management.

This treats of the best use of forest trees for planting on farms, and gives planting plans based upon the ideal practical relation between farmstead, woodlot, shelterbelt, and windbreak.

Foöest Planting Leafuets (Circulars 54-77, 82-95, and 106).

54. How to Cultivate and Care for Forest Plantations on the Semi-Arid Plains.

55. How to Pack and Ship Young Forest Trees.

56. Bur Oak.

57. Jack Pine.

58. Red Oak.

59. Eucalypts (Revised Edition).

60. Red Pine.

61. How to Transplant Forest Trees.

62. Shagbark Hickory.

63. Basswood.

64. Black Locust. (Revised Edition).

65. Norway Spruce.

66. White Elm.

67. White Pine.

68. Scotch Pine.

69. Fence-Post Trees.

70. European Larch.

71. Chestnut.
72. Western Yellow Pine.

73. Red Cedar.

74. Honey Locust.

75. Hackberry.

76. Silver Maple.

77. Cottonwood.

82. Hardy Catalpa.

83. Russian Mulberry (Revised Edition).

84. White Ash.

85. Slippery Elm.

86. Boxelder.

87. White Willow.

88. Black Walnut.

89. Tamarack.

90. Osage Orange.

91. Coffeetree.

92. Green Ash.

93. Yellow Poplar.

94. Black Cherry.

95. Sugar Maple.

106. White Oak.

\section{PHYSICAL PROPERTIES, SEASONING, AND PRESERVATIVE TREATMENT OF TIMBER.}

\section{Bulletin 6: Timber Physics, Part I: Preliminary Report.}

This discusses the need, object, and scope of investigations into the nature of our important woods, especially their mechanical and technical properties, giving references to preceding works and explaining the methods to be pursued by the Service (then the Division of Forestry), including the forms of record and illustrations of the machinery in use.

\section{*Bulletin 8: Timber Physics, Part II: Progress Report. Price, 15 cents.}

Contains the results of tests for strength made on longleaf pine prior to 1893 ; a comparative study of their significance, particularly as dependent on certain conditions of the test specimens; a comparison of bled and unbled timber, accompanied by a study into the chemical conditions of both, and an account of the general characteristics of longleaf pine timber, of the geographical distribution of the species, and of the experimental methods used in the tests.

* Bulletin 10: Timber: An Elementary Discussion of the Characteristics and Properties of Wood. Price, 10 cents.

A discussion of the characteristics and properties of wood in general, and of the American woods in particular, designed to be of service to engineers, architects, carpenters, lumbermen, and all woodworkers.

\section{Bulletin 41: Seasoning of Timber.}

A study of the general effects and advantages of seasoning timber, with especial reference to railroad ties and their preparation for preservative treatment, including tests of the rate at which seasoning takes place under different conditions and of the effect of different methods of piling ties. 
Bulletin 51: Report on the Condition of Treated Timbers Laid in Texas, February, 1902.

Results secured from various timbers which received preservative treatment and were then laid in an experimental track on the Gulf, Colorado and Santa Fe Railway near Pelican, Tex.

*Bulletin 70: Effect of Moisture on the Strength and Stiffness of Wood. Price, 15 cents.

The results of strength tests, principally on longleaf pine, spruce, and chestnut under compression parallel to grain, compression at right angles to grain, bending, and shearing. Factors are given for computing strength at $1^{\circ}$ of moisture from the known strength at another. The character and behavior of the test pieces are shown by plates, and curves furnish graphic illustration of the relation of strength to moisture. Special studies of case-hardening, prolonged soaking, resoaking, and soaking followed by drying, as well as discussion of the fiber-saturation point, are included.

Circular 12: Southern Pine: Mechanical and Physical Properties.

Circular 15: Summary of Mechanical Tests on Thirty-two Species of American Woods.

Three progress reports, of which the first two deal with the earlier series of timber tests conducted by the Division of Forestry.

Circular 38: Instructions to Engineers of Timber Tests.

Circular 39: Experiments on the Strength of Treated Timber.

A brief description of tests on treated timber, and of treating methods, begun at the St. Louis Exposition in 1904 and afterwards completed at the timber-testing station of the Service at Purdue University, Lafayette, Ind. The conclusions show that a high degree of steaming weakens wood; that zinc chlorid does not weaken wood under static loading, but may render it brittle under impact; and that the effect of creosote is not to weaken the wood, since it does not enter the cell walls, but apparently only retards seasoning.

Circular 40: The Utilization of Tupelo.

Circular 46: Holding Force of Railroad Spikes in Wooden Ties.

Circular 47: Strength of Packing Boxes of Various Woods.

Circular 48: Kiln-drying Hardwood Lumber.

A brief statement of the problem of hardwood kiln-drying and a description of the kilns and processes in common use.

Circular 80: The Fractional Distillation of Coal-Tar Creosote.

Circular 98: Quantity and Character of Creosote in Well-Preserved Timbers.

Circular 101: The Open-Tank Method for the Treatment of Timber.

Circular 103: Seasoning of Telephone and Telegraph Poles.

Circular 104: Brush and Tank Pole Treatments.

Circular 108: The Strength of Wood as Influenced by Moisture.

The points brought out in Service timber tests to determine the comparative strength of wood when green or resoaked and when dry, with formulas for calculating the strength of the tested woods at various degrees of moisture and also the margin of safety required in using timbers where they will be exposed to moisture. A briefer statement of the facts and laws given in Bulletin 70 .

Circular 111: Prolonging the Life of Mine Timbers.

A description of the different forms in which timber is used in mines and of the conditions which render the life of mine timbers so short; also of experiments in peeling and seasoning the timbers and in treating them by brush, in open-tanks, and in closed cylinders with creosote, cabolineum, and zinc chlorid, to determine what method of preservative treatment will give the greatest service at the least expense. 
Extract No. 395, from the Yearbook of the Department of Igriculture (1905): Prolonging the Life of Telephone Poles.

\section{FORESTRY AND LUMBERING.}

* Bulletin 34: A History of the Lumber Industry in the State of New York. Price, 20 cents.

\section{Bulletin 36: The. Woodsman's Handbook.}

Chiefly tables and rules for the measurement of wood and timber, including a comparison of $43 \mathrm{log}$ rules employed in the United States and Canada, with a brief statement concerning the origin and use of each.

Bulletin 61: Terms Used in Forestry and Logging.

A brief dictionary of words and phrases in use by forester and logger, prepared in cooperation with The Society of American Forester's, and designed to promote uniformity of usage and to serve as the basis for a more careful and exact forest terminology.

* Bulletin 71: Rules and Specifications for the Grading of Lumber. Price, 15 cents.

Presenting for the first time under one cover the grading rules and specifications adopted by the various lumber inanufacturers' associations throughout the country. As far as possible, the given grades are up-to-date at the time of going to press. It is urged that a standardization of grades be secured by cooperation among associations.

* Bulletin 73: Grades and Amount of Lumber Sawed from Yellow Poplar, Yellow Birch, Sugar Maple, and Beech. Price, 10 cents.

Showing, by tallies at the mill, the amount of lumber actually sawed out from certain kinds of trees of different sizes. It serves, first, to indicate the actual gain in quality of the lumber with the increase of the sizes of the trees; and, second, it set a limit below which trees yield too little lumber, or are too poor in quality, to pay for cutting. The tables enable the lumberman to tell how much lumber of each grade he may expect to saw from trees of each diameter. Thus he may not only avoid cutting at a loss, but may also foretell the quality increment which combines with the quantity increment to make up his future gain.

Circular 25: Forestry and the Lumber Supply.

Three addresses on the relation of the problem of lumber supply to applicd forestry. The first address was delivered by the President of the United States before The Society of American Foresters; the second by Mr. R. L. McCormack, president of the Mississippi Valley Lumbermen's Association; and the third by the Forester.

Extracts from Yearbooks of the Department of Agriculture:

No. 274: The Influence of Forestry upon the Lumber Industry (1902).

No. 398: Waste in Logging Southern Yellow Pine (1905).

No. 434: The National Forests and the Lumber Supply (1906).

An exposition of the place occupied by the National Forests in the lumber industry, showing how the Forests tend both to prevent the present wasteful disposal of timber at excessively low prices and, later, to check the too sudden rise in lumber prices which would otherwise follow overconsumption.

\section{FOREST FIRES.}

Circular 26: Forest Fires in the Adirondacks in 1903.

A report on the grat furest fires in the Adirondack region in 1903, with an estimate of the damage done and suggestions for controlling fires in the future.

Circular 79: The Control of Forest Fires at McCloud, California.

The first thoroughgoing plan of fire protection applied by a lumber company in the Tinited States. The protective measures while specifically designed for local conditions are of wicle interest and largely applicahle elsewhere. The actual costs, which are nnminal, are given, as well as the results secured. 
GRAZING.

* Bulletin 15: Forest Growth and Sheep Grazing in the Cascade Mountains of Oregon. Price, 5 cents.

A careful study of the grazing question as it was found to exist in 1897 .

* Bulletin 62: Grazing on the Public Lands. (Published also in the second partial report of the Public Lands Commission, Senate Document No. 189, 58th Cong., 3d sess.) Price, 15 cents.

A history of grazing on the public lands of the United States, with a comparison of the methods of grazing now and formerly in force, and recommendations as to the establishment of regulations governing grazing.

* Bulletin 72: Wolves in Relation to Stock, Game, and the National Forest Reserves. Price, 10 cents.

This bulletin shows the distribution of wolves in the United States, discusses the extent to which they prey upon stock and game, and gives directions for destroying them by shooting, trapping, and poisoning, and for wolf-proof fences. The effectiveness of bounties is also considered. The study upon which this bulletin is based was made in cooperation with the Biological Survey in the interest of those grazing stock on the National Forests.

FOREST LAW.

* Bulletin 57: Federal and State Forest Laws. Price, 15 cents.

A compilation of all the State and National laws relative to forests and forestry, including 1904 .

\section{FORESTS AND STREAM FLOW.}

Bulletin 44: The Diminished Flow of the Rock River in Wisconsin and Illinois, and Its Relation to the Surrounding Forests.

A discussion of the effect of forests upon stream flow with special reference to the region drained by the Rock River. The discussion is supplemented with practical advice as to the management of woodlands for increasing the water-storing capacicy of the soil as well as the profits of the individual owner.

Extract 329, from the Yearbook of the Department of Agriculture (1903): The Relation of Forests to Stream Flow.

Results of observations conducted in the San Bernardino Mountains, in southern California.

\section{TERMS OF COOPERATION OFFERED BY THE SERVICE,}

The following circulars, which may be had upon application to the Forester without charge, explain the terms of the cooperative agreements which the Forest Service will make with those desiring assistance in the care of their forests or woodlots and in the establishment or care of forest plantations.

Circular 21 (Fifth Revision): Practical Assistance to Farmers, Lumbermen, and Other Owners of Forest Lands.

Circular 22 (Fifth Revision): Practical Assistance to Tree Planters.

\section{FOREST STATISTICS.}

* Bulletin 74: Forest Products of the United States: 1905. Price, 15 cents.

A discussion of the lumber cut forms the chief part of the bulletin. Statistics on the production of cross-ties, tight cooperage stock, pulpwood, mine timbers, tanbark, veneer, wood used for distillation, and the production of lath and shingles are also included. This is the first detailed report on wood products of the United States ever published. Accurate knowledge of the annual drain upon our forests is highly important for lumbermen, timberland owners, and the general public.

[Cir. 36] 
Circular 42: Consumption of Tanbark in 1905.

Circular 44: Wood Used for Pulp in 1905.

Circular 49: Timber Used in the Mines of the United States in 1905.

Circular 52: The Lumber Cut of the United States in 1905.

Circular 78: Woods Used for Packing Boxes in New England.

Circular 97: The Timber Supply of the United States in 1905.

A discussion of the best stumpage estimates, showing the need of a new timber census.

Circular 107: Sawmill Statistics.

Circular 110: Exports and Imports of Forest Products, 1906.

Circular 116: The Waning Hardwood Supply.

A discussion of the consumption of hardwoods, based upon statistics, showing that the demand is gaining over production and that a hardwood shortage can be prevented only by guarded use of the hardwood forests yet remaining of the East and Southeast.

Table: Production of Lumber, Lath, and Shingles, States and Species, 1906, 1905, and 1904 .

\section{LOCATION, DATE OF LATEST PROCLAMATION. AND AREA OF THE NATIONAL FORESTS IN THE UNITED STATES, AlASKA, AND PORTO RICO.}

OCTOBER 1, 1907.

\begin{tabular}{|c|c|c|c|c|}
\hline State or Territory. & Forest. & $\begin{array}{l}\text { Date of latest } \\
\text { proclamation. }\end{array}$ & Area. & Total. \\
\hline California.... & 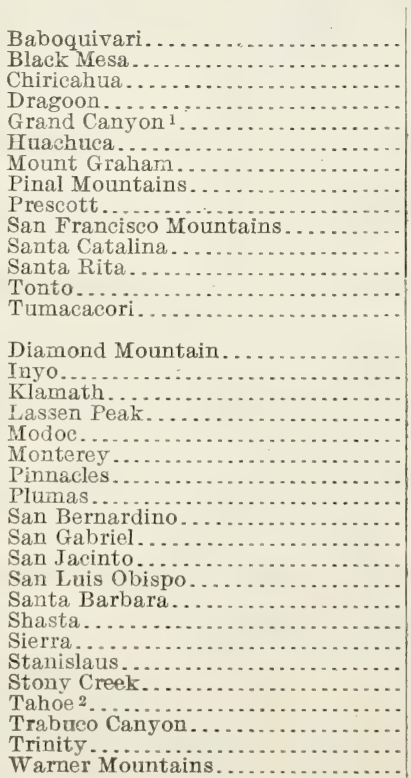 & 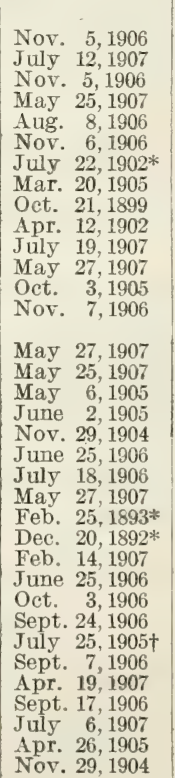 & $\begin{array}{r}\text { Acres. } \\
126,720 \\
2,584,480 \\
287,520 \\
69,120 \\
2,257,920 \\
314,125 \\
140,880 \\
45,760 \\
423,680 \\
1,975,310 \\
575,360 \\
416,558 \\
1,11,300 \\
203,550 \\
649,838 \\
221,324 \\
1,896,313 \\
897,115 \\
288,218 \\
335,195 \\
14,108 \\
787,742 \\
737,120 \\
555,395 \\
1,751,439 \\
363,350 \\
1,982,100 \\
1,523,770 \\
5,049,934 \\
1,296,800 \\
937,569 \\
1,394,772 \\
156,640 \\
1,243,042 \\
306,518\end{array}$ & $10,410,183$ \\
\hline
\end{tabular}

1 Game preserve created in the Grand Canyon National Forest by proclamation November 28, 1906.

2 Total of Tahoe in California and Nevada $=1,453,887$ acres.

* Minor modification by Executive order since date listed.

$\uparrow$ Minor modification by act of Congress since date listed.

[Cir. 36] 
Location, Date of Latest Proclamation, and Area of the National Forestg in the United States, Alaska, and Porto Rico-Continued.

October 1, 1907-Continued.

\begin{tabular}{|c|c|c|c|c|}
\hline State or Territory. & Forest. & $\begin{array}{l}\text { Date of latest } \\
\text { proclamation. }\end{array}$ & Area: & Total. \\
\hline Colorado...... & 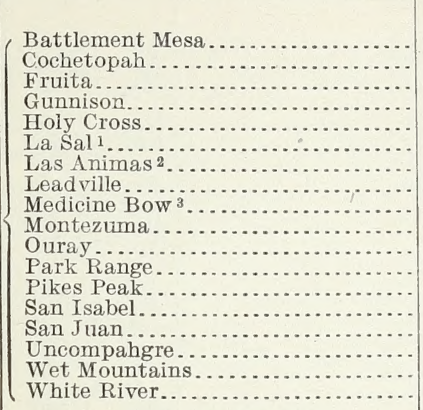 & $\begin{array}{lr}\text { June } & 5,1905 \\
\text { June } 13,1905 \\
\text { Feb. } 24,1906 \\
\text { May } 12,1905 \\
\text { Mar. } 1,1907 \\
\text { Jan. } 25,1906 \\
\text { Mar. } 1,1907 \\
\text { May } 12,1905 \\
\text { Sept. } 27,1907 \\
\text { Mar. } 2,1907 \\
\text { Feb. } 2,1907 \\
\text { Mar. } 1,1907 \\
\text { May } 12,1905 \\
\text { June } 12,1905 \\
\text { Mar. } 2,1907 \\
\text { Mar. } 1,1907 \\
\text { June } 12,1905 \\
\text { May } 21,1904\end{array}$ & $\begin{array}{r}\text { Acres. } \\
797,720 \\
1,133,330 \\
7,680 \\
901,270 \\
1,061,280 \\
29,502 \\
196,140 \\
1,219,947 \\
1,346,155 \\
1,612,146 \\
273,175 \\
1,133,686 \\
1,681,667 \\
321,227 \\
2,203,918 \\
619,428 \\
239,621 \\
970,880\end{array}$ & \\
\hline
\end{tabular}

Bear River ${ }^{4}$. . . . . . . . . . . . . . . . .

Bitter Root 5

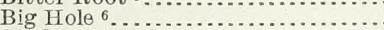

Caribou 7

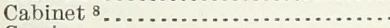

Cassia.

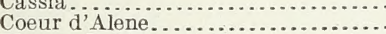

Henrys Lake.

Kootenai 9 -

Lemhi. . . . . . . . . . . . . . . . .

Palouse.

May 28, 1906

May 22, 1905

Mar. 1, 1907

Jan. 15,1907

Mar. 2, 1907

June 12,1905

Nov. 6, 1906

May 23, 1905

Idaho.

Payette.

Nov. 5,1906

Nov. 5, 1906

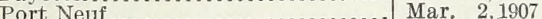

Pocatello

Priest River 10

Raft River 13

Salmon River.

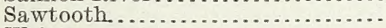

Weiser. .

Mar. 5, 1903

$\begin{array}{ll}\text { Mar. } & 2,1907 \\ \text { Nov. } & 5,1906\end{array}$

Nov. 5,1906

Nov. 6, 1906

Mar. 2, 1907

Mar. 2, 1907

Kansas.

Garden City.

July 25, 1905

Big Belt.

Big Hole 6 ..

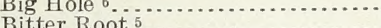

Cabinet 8

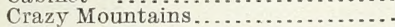

Elkhorn . . . . . . . . . . . . . . .

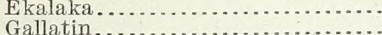

Gallatin.

Hell Gate.

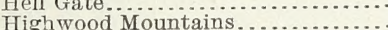

Kootenai ${ }^{9}$

Lewis and Clark. . . . . . . . . . . . . .

Little Belt.

Lolo.

Long Pine

Little Rockies.....................

Madison

415,360

$3,860,960$

304,140

733,000

494,560

326,160

$2,331,280$

798,720

165,242

$1,344,800$

194,404

$1,460,960$

99,508

49,920

815,100

293, 044

$1,879,680$

$3,340,160$

$1,126,429$

303,000

97,280

$20,336,427$

641,460
$1,612,960$

Mar. 1,1907

Mar. 1, 1907

May 22, 1905

Mar. 2, 1907

Aug. 10, 1906

May 12, 1905

Nov. 5, 1906

Mar. 7,1906

Apr. 12,1906

Sept. 14,1906

Dec. 12,1903

Nov. 5, 1906

Mar. 2, 1907

Feb. 15, 1907

Nov 6,1906

Sept. 24, 1906

Mar. 2, 1907

Oct. 3, 1905

Missoula.............................. 6,1906

Otter

Pryor Mountains................ June 1, 1907

Snowy Mountains ............. Nov. 5, 1906

Yellowstone $12 \ldots . . \ldots \ldots \ldots \ldots . . \ldots \ldots$ Mar. 2, 1907

691,920

$1,566,400$

234,760

186,240

33,808

888,660

782,160

$1,582,400$

45,080

887,360

$5,541,180$

$1,053,160$

$1,211,680$

111,445

31, 000

958,800

194, 430

590,720

78,733

126,080

$1,352,240$

1 Total of La Sal in Colorado and Utah $=158,462$ acres

2 Total of Las Animas in Colorado and New Mexico $=196,620$ acres.

3 Total of Medicine Bow in Colorado and Wyoming $=1,907,767$ acres.

4 Total of Bear River in Idaho and Utah $=683,280$ acres.

5 Total of Bitter Root in Idaho and Montana $=4,552,880$ acres.

6 Total of Big Hole in Idaho and Montana $=1,917,100$ acres.

7 Total of Caribou in Idaho and Wyoming $=740,740$ acres.

8 Total of Cabinet in Idaho and Montana $=2,050,960$ acres.

9 Total of Kootenai in Idaho and Montana $=1,052,602$ acres.

10 Total of Priest River in Idaho and Washington $=1,221,620$ acres.

11 Total of Raft River in Idaho and Utah $=410,247$ acres. ${ }^{2}$

12 Total of Yellowstone in Idaho, Montana, and Wyoming $=8,317,880$ acres.

[Cir. 36] 
Location, Date of Latest Proclamation, and Area of the National Forests in the United States, Alaska, and Porto Rico-Continued.

October 1, 190\%-Continued.

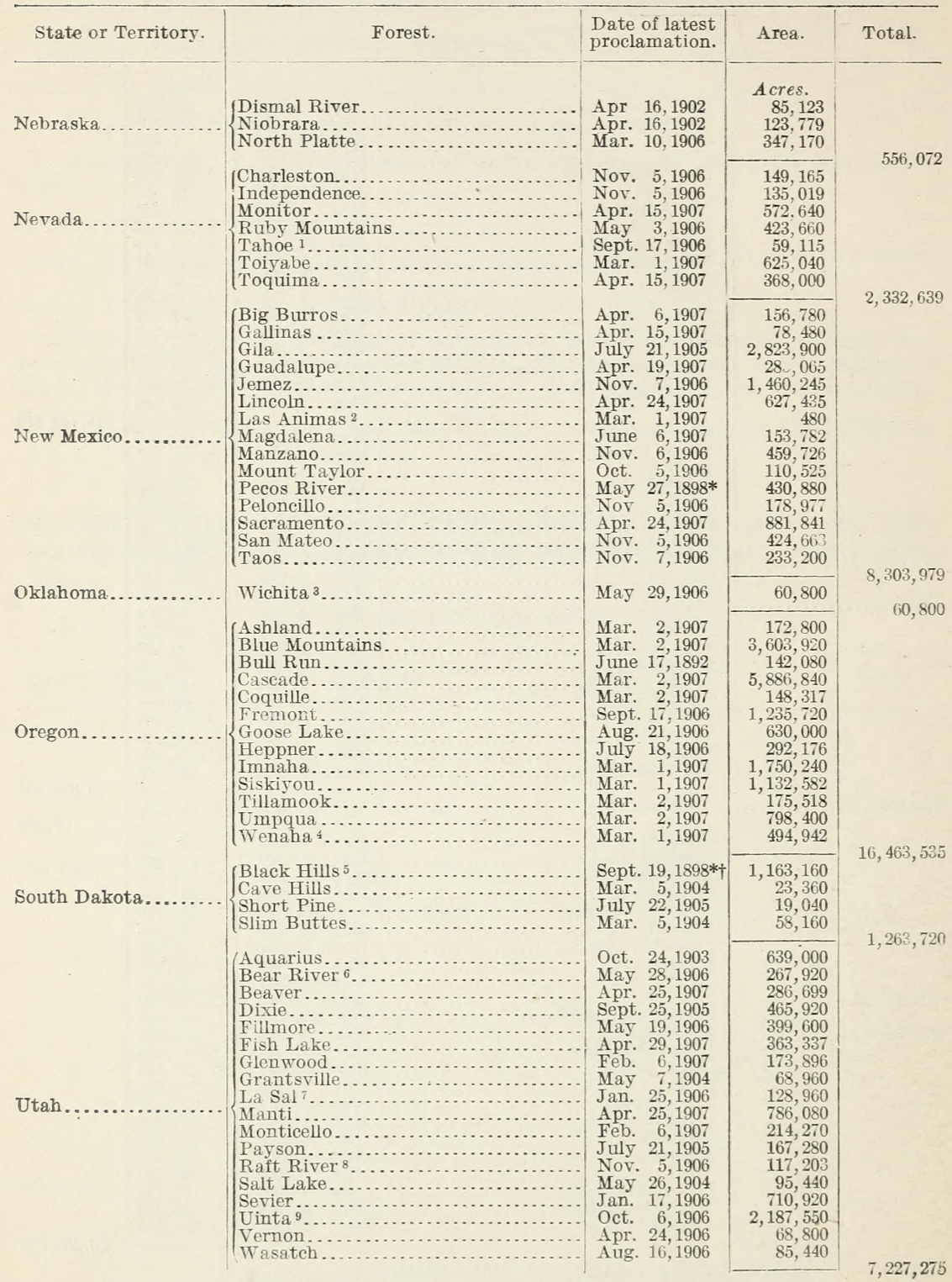

1 Total of Tahoe in Nevada and California $=1,453,887$ acres.

2 Total of Las Animas in New Mexico and Colorado $=196,620$ acres.

a Game preserve created in the Wichita National Forest by proclamation June 2, 1905.

1 Total of Wenaha in Oregon and Washington $=813,342$ acres.

5 Total of Black Hills in South Dakota and Wyoming $=1,209,600$ acres.

${ }^{6}$ Total of Bear River in Utah and Idaho $=683,280$ acres.

7 Total of La Sal in Utah and Colorado $=158,462$ acres.

8 Total of Raft River in Utah and Idaho $=410,247$ acres.

9 Total of Uinta in Utah and Wyoming $=2,192,146$ acres.

* Minor modification by Executive order since date listed.

+ Minor modification by act of Congress since date listed. 
Location, Date of Latest Proclamation, and Area of the National Forests in the United States, Alaska, and Porto Rico-Continued.

October 1, 190\%-Continued.

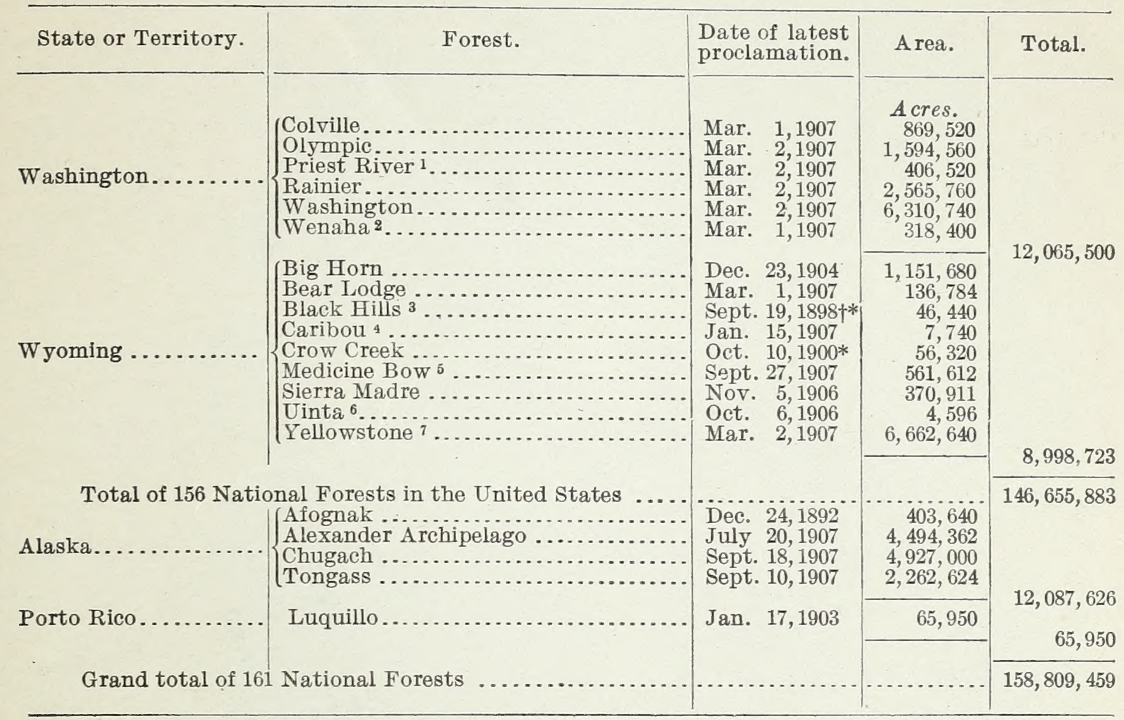

1 Total of Priest River in Washington and Idaho $=1,221,620$ acres.

2 Total of Wenaha in Oregon and Washington $=813,342$ acres.

3 Total of Black Hills in Wyoming and South Dakota $=1,209,600$ acres.

4 Total of Caribou in Wyoming and Idaho $=740,740$ acres.

5 Total of Medicine Bow in W yoming and Colorado $=1,907,767$ acres.

6 Total of Uinta in Wyoming and Utah $=2,192,146$ acres.

7 Total of Yellowstone in W yoming, Montana, and Idaho =8,317,880 acres.

* Minor modification by Executive order since date listed.

$\dagger$ Minor modification by act of Congress since date listed.

[Cir. 36] 
